\title{
NOTE
}

\section{Proposal of ATCC 19698 as the Neotype Strain of Mycobacterium paratuberculosis Bergey et al. 1923}

\author{
R. S. MERKAL \\ National Animal Disease Center, Agricultural Research, Science and Education Administration, U.S. \\ Department of Agriculture, Ames, Iowa 50010
}

\begin{abstract}
American Type Culture Collection (ATCC) strain 19698 is here proposed as the neotype strain of Mycobacterium paratuberculosis Bergey et al. 1923. No culture of any of the strains on which the original description of this organism was based is known to be extant. A working type, ATCC 12227, is used for vaccine and paratuberculin production, but this strain is atypical of the species in that it lacks most of the distinctive properties of the species, including mycobactin requirement and pathogenicity. ATCC 19698 possesses the characters given in the original description of $M$. paratuberculosis as well as those of the current concept of this species.
\end{abstract}

Jöhne and Frothingham (4) published their discovery of a pecuilar kind of "tuberculosis" in a cow in 1895. A few years later, Bang $(1,2)$ showed that the disease was not identical to tuberculosis and suggested the name paratuberculosis for it. The term Johne's disease frequently is used for the clinical condition, and the term Johne's bacillus is used for the organism. All attempts to culture the causative organism failed until Twort and Ingram $(11,12)$ in 1910 found that the addition of some types of killed mycobacteria other than the pathogen to the culture medium provided an "essential substance," now known as mycobactin, which allowed the growth of the causative organism. (Mycobactin is the mycobacterial product regularly required as an iron-chelating agent for growth of Mycobacterium paratuberculosis.) They referred to the disease as pseudotuberculosis enteritis and to the causative organism as Mycobacterium enteritidis chronicae pseudotuberculosae bovis. Bergey et al. (3) were the first to propose a validly published name for this organism, Mycobacterium paratuberculosis, but no type strain was established. No culture of any of the strains on which the original description of this organism was based is known to be extant. Sneath and Skerman (10) listed American Type Culture Collection (ATCC) 12227 as a "working type" of $M$. paratuberculosis. ATCC 12227 is U.S. Department of Agriculture strain 18, obtained by the ATCC through D. A. Porter, Regional Animal Disease Laboratory, Auburn, Ala. The major thrust of the Mycobacteriosis Research Unit since its inception in 1939 at Auburn has been paratuberculosis research, and I have been employed as a microbiologist in the unit since 1953. Many paratuberculous animals are examined and hundreds of primary cultures of $M$. paratuberculosis are made annually. The Mycobacteriosis Research Unit at Auburn, its cultures, and its laboratory records were moved to the National Animal Disease Center (NADC), Ames, Iowa, in 1961. Our records indicate that strain 18 had been isolated by W. A. Hagan at Cornell University in 1928. It had adapted to growth on Long synthetic medium without a mycobactin source by February 1933. It was transmitted to the Auburn Laboratory on 20 October 1939. At the request of the ATCC, cultures of strain 18 were submitted several times, and the last cultures of strain 18 were sent to the ATCC on 24 October 1966.

Strain 18 has many antigenic properties similar to those of newly isolated $M$. paratuberculosis strains, and it is used for vaccine and johnin (paratuberculin) production because it grows profusely and relatively rapidly as a surface pellicle on synthetic liquid medium without mycobactin. However, it is dissimilar to recently isolated $M$. paratuberculosis strains in those cultural characteristics as well as in being nonpathogenic for calves by either oral or intraarterial administration. Because strain 18 was isolated well after the original description of $M$. paratuberculosis was published, it cannot be considered for designation as the type strain of this organism.

At the request of the ATCC to establish a neotype, I submitted cultures of a newly isolated 
strain (NADC 5617) of $M$. paratuberculosis on 24 October 1966 . These were accessioned by the ATCC under the number 19698. Freeze-dried samples of ATCC 19698 were returned to me (12 December 1973) for checking of purity, viability, and identity. They were found to conform to the description of this species both as given in the current edition of Bergey's Manual of Determinative Bacteriology by Runyon et al. (9) and as given by Twort and Ingram (12), the first to describe the organism. Additional characteristics of this strain have been given by Merkal and co-workers (5-8). This strain was among those studied by Merkal et al. (8) and Merkal and Curran (6). Because a neotype strain has, to date, not been proposed for this organism, ATCC 19698 is here proposed as the neotype strain of M. paratuberculosis Bergey et al.

\section{REPRINT REQUESTS}

Address reprint requests to: Dr. R. S. Merkal, P.O. Box 70, National Animal Disease Center, Agricultural Research, Science and Education Administration, Department of Agriculture, Ames, IA 50010.

\section{LITERATURE CITED}

1. Bang, B. 1906. Chronische pseudotuberculöse Darmentzündung beim Rinde. Berl. Tierearztl. Wochenschr. 22: 759-763.

2. Bang, B. 1909. Die spezifische chronische Enteritis des
Rindes, p. 137-162. In V. Adseren (ed.), Bernard Bang: selected works. Levin and Munksgaard, Copenhagen.

3. Bergey, D. H., F. C. Harrison, R. S. Breed, B. W. Hammer, and F. M. Huntoon. 1923. Bergey's manual of determinative bacteriology. p. 374-375. The Williams \& Wilkins Co., Baltimore.

4. Jöhne, H. A., and L. Frothingham. 1895. Ein eigenthümlicher Fall von Tuberculose beim Rinde. Dtsch. Z Tiermed. Vgl. Pathol. 21:438-454.

5. Merkal, R. S. 1973. Laboratory diagnosis of bovine paratuberculosis. J. Am. Vet. Med. Assoc. 163:1100-1102.

6. Merkal, R. S., and B. J. Curran. 1974. Growth and metabolic characteristics of Mycobacterium paratuber culosis. Appl. Microbiol. 28:276-279.

7. Merkal, R. S., K. E. Kopecky, A. B. Larsen, and J. R. Thurston. 1964. Improvements in the techniques for primary cultivation of Mycobacterium paratubercu. losis. Am. J. Vet. Res. 25:1290-1293.

8. Merkal, R. S., K. R. Rhoades, and J. E. Gallagher. 1973. Scanning electron microscopy of mycobacteria. Am. Rev. Respir. Dis. 108:381-387.

9. Runyon, E. H., L. A. Wayne, and G. P. Kubica. 1974 Family II. Mycobacteriaceae Chester, 1897, 63, p. 681701. In R. E. Buchanan and N. E. Gibbons (ed.), Bergey's manual of determinative bacteriology, 8th ed. The Williams \& Wilkins, Co., Baltimore.

10. Sneath, P. H. A., and V. B. D. Skerman. 1966. A list of type and reference strains of bacteria. Int. J. Syst. Bacteriol. 16:1-33.

11. Twort, F. W. 1910. A method for isolating and growing the lepra bacillus of man (preliminary note). Proc. R. Soc. London Ser. B. 83:156-158.

12. Twort, F. W., and G. L. Y. Ingram. 1912. A method for isolating and cultivating Mycobacterium enteritidis chronicae pseudotuberculosae bovis, Jöhne, and some experiments on the preparation of a diagnostic vaccine for pseudotuberculosis enteritis of bovines. Proc. $R$. Soc. London Ser. B. 84:317-542. 